\title{
EVALUATION OF METHODS FOR DURATION OF PRESERVATION OF RNA QUALITY IN RAT LIVER USED FOR TRANSCRIPTOME ANALYSIS
}

\author{
Toshihiko KASAHARA ${ }^{1}$, Toshiko MIYAZAKI ${ }^{1}$, Hiroyuki NITTA ${ }^{1}$, Atsushi ONO ${ }^{1}$, \\ Toshikazu MIYAGISHIMA ${ }^{1}$, Taku NAGAO ${ }^{2}$ and Tetsuro URUSHIDANI ${ }^{1,3}$ \\ ${ }^{1}$ Toxicogenomics Project, National Institute of Biomedical Innovation, \\ 7-6-8 Asagi, Ibaraki, Osaka 567-0085, Japan \\ ${ }^{2}$ National Institute of Health Sciences, 1-18-1 Kamiyoga, Setagaya-Ku, Tokyo 158-8501, Japan \\ ${ }^{3}$ Department of Pathophysiology, Faculty of Pharmaceutical Sciences, \\ Doshisha Women's College of Liberal Arts, Kodo, Kyotanabe, Kyoto 610-0395, Japan
}

(Received August 23, 2006; Accepted September 11, 2006)

\begin{abstract}
In The Toxicogenomics Project, about 150 chemicals are administered to rats, and gene expression in the liver analyzed by Affymetrix GeneChip and stored in the database. As the quality of RNA greatly influences the accuracy of gene expression data, conditions of the storage of the sample are very important. Recently, an RNA stabilization solution, RNAlater ${ }^{\circledR}$, has become commercially available. In this study, the new storage method was compared with the traditional storage method (stored in freezer or liquid nitrogen) under various conditions by looking at the degradation of RNA assessed by its total yield, OD260/280 ratio, 28S/18S ratio, and quantity of $\beta$-actin. It was confirmed that RNAlater ${ }^{\circledR}$ preserved the liver tissue sample by maintaining the quality of RNA for one year (in liquid $\mathrm{N}_{2}$ or $-80^{\circ} \mathrm{C}$ ), for 3 days $\left(4^{\circ} \mathrm{C}\right.$ ), or for $2 \mathrm{hr}$ (room temperature) without degradation of RNA. Quality of RNA samples dissolved in buffer RLT and stored at $-20^{\circ} \mathrm{C}$ tended to decrease, but samples stored at $-80^{\circ} \mathrm{C}$ were almost equivalent to those stored in liquid nitrogen. In conclusion, we recommend the following procedure for preservation of liver tissue for extraction of RNA: 1) tissues removed should be put into chilled RNAlater ${ }^{\circledR}$ as soon as possible; 2) samples in RNAlater ${ }^{\circledR}$ must be stored overnight or longer at $4{ }^{\circ} \mathrm{C}$ and can be left for as long as 2 weeks without freezing; 3) samples in RNAlater ${ }^{\circledR}$ can be stored for at least one year under less than $-20^{\circ} \mathrm{C}$ and 4) samples dissolved in buffer RLT can be preserved at least for one year under $-80^{\circ} \mathrm{C}$.
\end{abstract}

KEY WORDS: mRNA stability, Rat, Liver

\section{INTRODUCTION}

The Toxicogenomics Project is a 5-year collaborative project conducted by the National Institute of Health Sciences (NIHS) and 17 pharmaceutical companies in Japan that started in 2002 (Urushidani and Nagao, 2005). In April 2005, some rearrangements were made and the project is now conducted by NIHS, the National Institute of Biomedical Innovation, and 15 pharmaceutical companies. Its aim is to construct a large-scale toxicology database of transcriptome for prediction of toxicity of new chemical entities in the early stage of drug development. About 150 chemicals, mainly medical compounds, have been selected, and administered to rats to obtain gene expression profile in the liver (also in kidney in some cases) using Affymetrix GeneChip in addition to traditional toxicological measures, including body/organ weight, blood biochemistry, hematology and histopathology. In order to overcome the species difference, bridging experiments are also performed using primary cultures of human and rat hepatocytes. Needless to say, the quality of the data should be good in order to create a drug safety predicting system with high accuracy. Since RNA is quite labile, it is quite important to preserve tissues, stabilizing the RNA for experiments of gene expression profiling. So far, isolated tissues had been promptly frozen in liquid nitrogen and then kept as such or in a deep

Correspondence: Tetsuro URUSHIDANI (E-mail: turushid@ dwc.doshisha.ac.jp) 
freezer. However, this is costly and may be risky if the freezer is in trouble, and prompt melting is required to ensure the quality of RNA. Recently, a new RNA stabilization solution, RNAlater ${ }^{\circledR}$ (Ambion, Austin, TX, USA) has become commercially available and is used in many laboratories (Grotzer et al., 2000; Wang et al., 2001; Rodrigo et al., 2002; Mutter et al., 2004). According to the manufacturer's notes, RNAlater ${ }^{\circledR}$ makes it possible to preserve tissues at a relatively high temperature and to repeat freezing-thawing, keeping the RNA stabilized. This is quite convenient, especially in our project, where vast numbers of samples are processed. To assess the usefulness of this product, we checked the following points:

1) Effects of the conditions (temperature and period) of fixing before freezing the sample.

2) Long-term preservation of samples fixed with RNAlater ${ }^{\circledR}$ at $4^{\circ} \mathrm{C}$ overnight compared with traditional procedures (liquid $\mathrm{N}_{2}$ or freezers).

3) Effects of freezing-thawing on the RNA quality in the sample.

4) Stability of RNA in the sample dissolved in Buffer RLT.

The quality of RNA was estimated by the amount of total RNA, the OD260/280 ratio, 28S/18S ratio on agarose electrophoresis, and the amount $\beta$-actin mRNA quantified by RT-PCR. Based on the results of these assessments, we determined the standard protocol of sample preservation for our project.

\section{MATERIALS AND METHODS}

\section{Preparation of total RNA}

Male Sprague-Dawley rats were purchased from Charles River Japan Inc., (Atsugi, Japan) and used at 10 weeks of age. The animals were killed by exsanguination under anesthesia, and the livers removed quickly and provided for each experiment. The weights of microtubes with $0.5 \mathrm{~mL}$ RNAlater ${ }^{\circledR}$ were measured in advance. A piece of liver tissue $(\sim 50 \mathrm{mg})$ was cut out by using a disposable biopsy punch $(\phi=5 \mathrm{~mm}$, Kai Industries, Gifu, Japan) and put into the pre-weighed microtube with or without RNAlater ${ }^{\circledR}$. Total RNA was isolated using the RNeasy kit. The liver tissue was homogenized in $0.5 \mathrm{~mL}$ RLT with a Mill Mixer (Qiagen) and zirconium beads. The lysate corresponding to ca. $20 \mathrm{mg}$ tissue was transferred to a microtube with an equivalent volume of chloroform, and $3 \mathrm{vol}-$ umes of TRIzol LS Reagent (Invitrogen life technologies, Carlsbad, CA, USA) were added to the homogenate. The mixture was then shaken vigorously for $30 \mathrm{~s}$, let stand at room temperature for $5 \mathrm{~min}$ and centrifuged thereafter at $12,000 \mathrm{~g}$ for $15 \mathrm{~min}$. The resultant aqueous layer was transferred to a new tube. To the aqueous solution, an equivalent volume of $50 \%$ ethanol was added and mixed by pipetting. The whole mixture was transferred to an RNeasy mini column. The following procedure was performed according to the user's manual. Finally, absorbance of the purified RNA fraction was measured spectrophotometorically at 260 and 280 $\mathrm{nm}$.

\section{Electrophoresis of total RNA}

To confirm the quality of total RNA, the total RNA solution $(1 \mu \mathrm{l})$ was applied to $1 \%$ agarose gelelectrophoresis, and we then visualized the bands of 28S and 18S with ethidium bromide under UV light. Band density was measured by light capture (Atto Co., Tokyo, Japan).

\section{Preparation of cDNA and Real-time PCR}

Synthesis of complementary DNA (cDNA) from total liver RNA $(2 \mu \mathrm{g})$ was performed by SuperScript II First-strand Synthesis System for RT-PCR (Invitrogen). Real-time PCR was performed by using "ABI PRISM 7900 Sequence Detection System" (Applied Biosystems, Foster City, CA, USA) according to the manufacturer's protocol in which $5 \mu$ of each cDNA preparation (1/10 dilution) or appropriately diluted standard DNA was added to a $20 \mu \mathrm{l}$ reaction mixture containing $10 \mu \mathrm{l}$ of "SYBR Green PCR Master Mix" (Applied Biosystems), $100 \mathrm{nM}$ of each primer and DEPC-water in $0.2 \mathrm{ml}$ MicroAmp optical tubes (Applied Biosystems). The thermal cycling condition comprised initial denaturation (at $95^{\circ} \mathrm{C}$ for $10 \mathrm{~min}$ ) and extension $\left(40\right.$ cycles at $95^{\circ} \mathrm{C}$ for $15 \mathrm{sec}$ and $60^{\circ} \mathrm{C}$ for 1 min). Copies of $\beta$-actin mRNA were quantified and presented as copy number per total RNA $(\mu \mathrm{g})$. Standard DNA and primer sets for $\beta$-actin were prepared according to Kasahara et al. (2005).

\section{Statistical analysis}

Parametric data were analyzed by the F test followed by the Student's $t$-test (Snedecor and Cochran, 1989). A value of $\mathrm{p}<0.01$ or 0.05 was considered to be statistically significant.

\section{RESULTS}

Effects of conditions (temperature and period) of fixing before freezing the sample

According to the manufacturer's protocol, the tis- 
Methods for preservation of mRNA quality.

sues were to be fixed in RNAlater ${ }^{\circledR}$ solution before storage. We varied the time and temperature, i.e., rat liver tissues were soaked in RNAlater ${ }^{\circledR}$ and kept for 1 , 3,8 , and 15 days under room temperature or in a refrigerator $\left(4^{\circ} \mathrm{C}\right)$, and the quality of RNA was checked (Fig.
1). The total RNA yield and OD260/280 ratio of the samples soaked in RNAlater ${ }^{\circledR}$ and kept under room temperature or in a refrigerator were unchanged for the entire period from the first day, whereas the $28 \mathrm{~S} / 18 \mathrm{~S}$ ratio of the sample kept under room temperature was

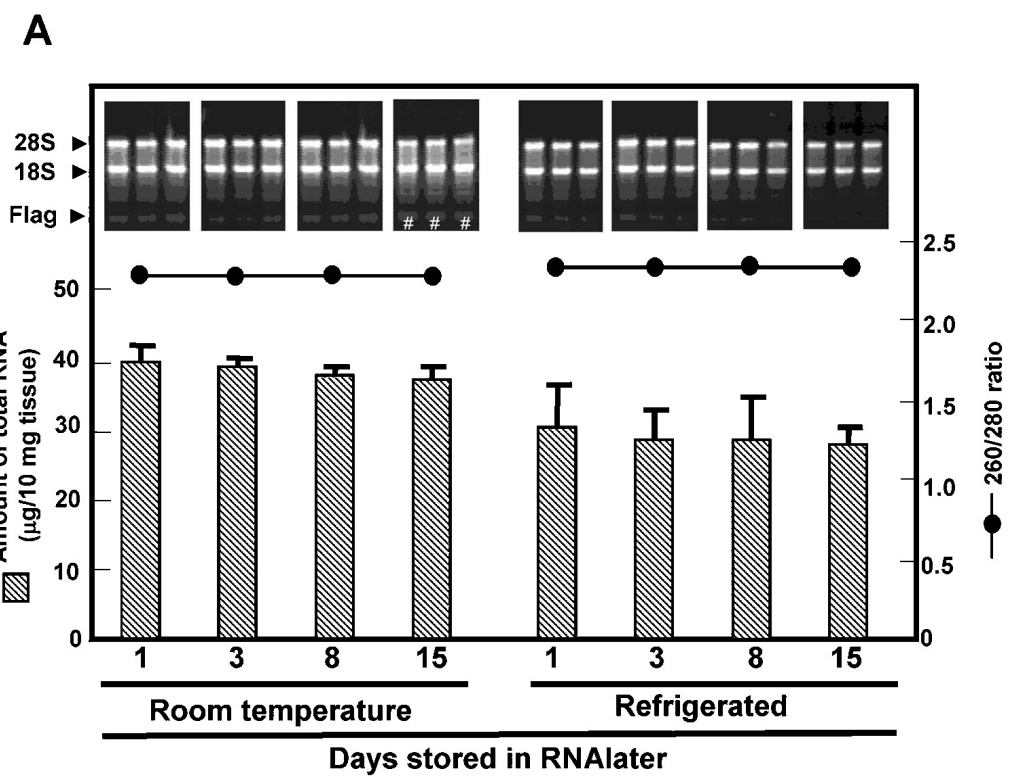

B

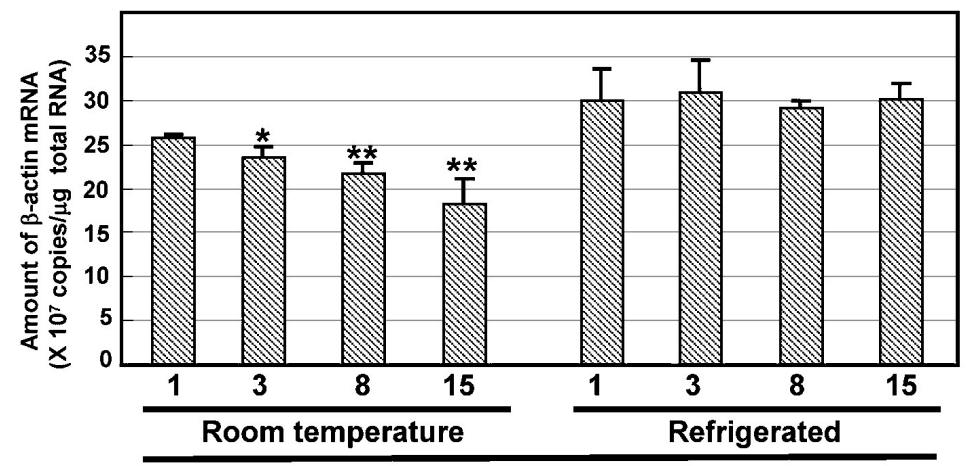

Days stored in RNAlater

Fig. 1. Influence of temperature and time on RNA quality of rat liver in RNAlater ${ }^{\circledR}$.

A: Rat liver tissue was soaked in RNAlater $^{\circledR}$ for $1,3,8$ or 15 days under room temperature or in a refrigerator $\left(\right.$ at $\left.4{ }^{\circ} \mathrm{C}\right)$. Total RNA was extracted from each tissue, and the amount of total RNA (bar braph) and the 260/280 ratio (line graph) were calculated and expressed as the mean \pm SD $(n=3)$. Total RNA was subjected to agarose gel-electrophoresis (upper photos), band density of $28 \mathrm{~S}$ and $18 \mathrm{~S}$ was measured by densitometer, and the ratio of the $28 \mathrm{~S} / 18 \mathrm{~S}$ band density was calculated. The Flags indicate the degradation of RNA with the following; \#; $0.8 \sim 1$, \#\#; 0.8. B: Real-time PCR of $\beta$-actin was performed using cDNA synthesized from the total RNA. The amount of expression of $\beta$-actin mRNA was expressed as copy number per $1 \mu \mathrm{g}$ of total RNA. $*, * *$ Significantly different from the sample at 1 day by Student's $t$-test: ${ }^{*} \mathrm{p}<0.05$;** $<<0.01$. 
found to be abnormal at the 15th day (Fig. 1A). The amount of $\beta$-actin mRNA in samples kept in the refrigerator was unchanged throughout the experimental period, whereas this parameter significantly decreased in samples kept for 3 days or more at room temperature (Fig. 1B).

Long-term preservation of samples fixed with RNAlater ${ }^{\circledR} 4^{\circ} \mathrm{C}$ overnight compared with the traditional procedure (liquid $\mathrm{N}_{2}$ or freezers)

In the next experiment, isolated liver tissues were soaked in RNAlater ${ }^{\circledR}$, stored overnight in the refrigerator, and then kept at -80 or $-20^{\circ} \mathrm{C}$, or at $-80^{\circ} \mathrm{C}$ after removing RNAlater ${ }^{\circledR}$. As a comparison, isolated tissues were frozen in liquid $\mathrm{N}_{2}$ and kept in liquid $\mathrm{N}_{2}$ or in a freezer at -20 or $-80^{\circ} \mathrm{C}$. Their RNA quality was checked at 1, 7 days and 1, 3, 6, and 12 months later. A comparison was made against the sample kept at $-80^{\circ} \mathrm{C}$ with RNAlater ${ }^{\circledR}$ for each time point. These protocols and the results are summarized in Tables $1-4$.
At one day, the only detectable change was found in the total RNA yield of fresh sample stored at $-20^{\circ} \mathrm{C}$, and the other parameters were unchanged. At the 7-day stock, the total yield of RNA from the fresh sample stored in liquid $\mathrm{N}_{2}$ and the sample stored in RNAlater ${ }^{\circledR}$ at $-20^{\circ} \mathrm{C}$ was significantly reduced (Fig. 2-II, C, D; Table 1). Abnormal S28/S18 ratios were observed in one out of 4 fresh samples stored at $-80^{\circ} \mathrm{C}$ and in all 4 samples stored at $-20^{\circ} \mathrm{C}$. Obvious degradation of RNA was observed in all the fresh samples stored for 7 days at $-20^{\circ} \mathrm{C}$ (Fig. 2-II, F; Table 3), so further preservation was ceased at that point.

At one-month stock, fresh samples stored in liquid $\mathrm{N}_{2}$ or at $-80^{\circ} \mathrm{C}$ showed significant reduction in the RNA yield with normal S28/S18 ratio (Fig. 2-III, D, E; Table 1,3$)$. The amount of $\beta$-actin mRNA was significantly decreased in the fresh sample stored at $-80^{\circ} \mathrm{C}$, whereas it increased in the sample RNAlater ${ }^{\circledR}$-pretreated, stored at $-80^{\circ} \mathrm{C}$, soaked in RNAlater ${ }^{\circledR}$ and stored at $-80^{\circ} \mathrm{C}$ (Fig. 2-III, B, C, E; Table 4).

Table 1. Evaluation of the methods with and without RNAlater ${ }^{\circledR}$ for preservation of the total RNA in the tissue.

\begin{tabular}{|c|c|c|c|c|c|c|}
\hline \multirow{2}{*}{$\frac{\text { Total RNA yield }}{\text { Storage method }}$} & \multicolumn{6}{|c|}{ Storage period } \\
\hline & 1-day & 7-days & 1-month & 3-months & 6-months & 12-months \\
\hline (a) RNAlater ${ }^{\circledR},-80^{\circ} \mathrm{C}$ & N.E. & N.E. & N.E. & N.E. & N.E. & N.E. \\
\hline (b) RNAlater ${ }^{\circledR}$ (removed), $-80^{\circ} \mathrm{C}$ & ----- & ----- & ----- & ----- & ----- & ----- \\
\hline (c) RNAlater ${ }^{\circledR},-20^{\circ} \mathrm{C}$ & ---- & $\downarrow$ & ----- & ----- & ----- & ----- \\
\hline (d) Raw tissue in liq. $\mathrm{N}_{2}$ & ----- & $\downarrow$ & $\downarrow$ & $\downarrow$ & $\downarrow$ & $\downarrow$ \\
\hline (e) Raw tissue, $-80^{\circ} \mathrm{C}$ & ----- & ----- & $\downarrow$ & $\downarrow$ & $\downarrow$ & $\downarrow$ \\
\hline (f) Raw tissue, $-20^{\circ} \mathrm{C}$ & $\downarrow$ & ----- & N.P. & N.P. & N.P. & N.P. \\
\hline
\end{tabular}

N.E.: not evaluated, -----: no change, $\downarrow$ : decreased (p<0.05) vs. method (a), N.P.: not performed. Storage method (a): Isolated liver tissues were soaked in RNAlater ${ }^{\circledR}$ and stored overnight in the refrigerator, and then kept at $-80^{\circ} \mathrm{C}$ (in a deep freezer). (b) Liver tissues were treated as (a) but stored at $-80^{\circ} \mathrm{C}$ after removing RNAlater ${ }^{\circledR}$. (c) Liver tissues treated as (a) and kept at $-20^{\circ} \mathrm{C}$ (in a freezer) in RNAlater ${ }^{\circledR}$. (d) Liver tissues were immediately frozen in liquid $\mathrm{N}_{2}$ and kept in liquid $\mathrm{N}_{2}$. (e) Frozen tissues were kept at $-20^{\circ} \mathrm{C}$ (in a freezer). (f) Frozen tissues were kept at $-80^{\circ} \mathrm{C}$ (in a deep freezer). On the assumption that method (a) was the best, comparisons were made against (a) at each time point.

Table 2. Evaluation of methods with and without RNAlater ${ }^{\circledR}$ for preservation of the quality of RNA (OD 260/280 ratio) in the tissue.

\begin{tabular}{|c|c|c|c|c|c|c|}
\hline \multirow{2}{*}{$\frac{\text { O.D. } 260 / 280 \text { ratio }}{\text { Storage method }}$} & \multicolumn{6}{|c|}{ Storage period } \\
\hline & 1-day & 7-days & 1-month & 3-months & 6-months & 12-months \\
\hline (a) RNAlater ${ }^{\circledR}-80^{\circ} \mathrm{C}$ & ----- & ----- & ----- & ---- & ----- & ---- \\
\hline (b) RNAlater ${ }^{\circledR}$ (removed), $-80^{\circ} \mathrm{C}$ & ----- & ----- & ----- & ----- & ----- & ----- \\
\hline (c) RNAlater ${ }^{\circledR}-20^{\circ} \mathrm{C}$ & ----- & ----- & ----- & ----- & ----- & ----- \\
\hline (d) Raw tissue in liq. $\mathrm{N}_{2}$ & ----- & ----- & ----- & ----- & ----- & ----- \\
\hline (e) Raw tissue $-80^{\circ} \mathrm{C}$ & ----- & ----- & ----- & ----- & ----- & ----- \\
\hline (f) Raw tissue $-20^{\circ} \mathrm{C}$ & ----- & ----- & N.P. & N.P. & N.P. & N.P. \\
\hline
\end{tabular}

----: no change N.P.: not performed. Storage methods (a) - (f) are described in Table 1. 
Methods for preservation of mRNA quality.

For storage for 3 months, there were significant reductions of total RNA in fresh samples stored in liquid $\mathrm{N}_{2}$ or at $-80^{\circ} \mathrm{C}$, and abnormal S28/S18 ratio and significant reduction of $\beta$-actin mRNA were observed in fresh samples stored at $-80^{\circ} \mathrm{C}$ as well (Fig. 2-IV, D, E; Table 1, 3, 4). For 6-month storage, both fresh samples stored in liquid $\mathrm{N}_{2}$ and at $-80^{\circ} \mathrm{C}$ showed significant reduction of total RNA, abnormal S28/S18 ratio, and significant reduction of $\beta$-actin mRNA (Fig. 2-V, D, E, Table 1, 3, 4). After 12 months of storage, although obvious degradation of RNA was observed in fresh samples stored in liquid $\mathrm{N}_{2}$ or at $-80^{\circ} \mathrm{C}$, the extent was less than that at 6 months (Fig. 2-VI, D, E; Table 1, 3, 4).

\section{Influence of time to processing on stability of RNA in frozen samples}

When RNA extraction is performed for vast numbers of frozen samples at once, the stability of RNA may be affected since the thawing time is long and varied. In this experiment, fresh samples frozen immediately in liquid $\mathrm{N}_{2}$ or samples treated with RNAlater ${ }^{\circledR}$ and then frozen were returned to room temperature for various times, and the quality of extracted RNA was checked. In fresh samples, no abnormality in total RNA and OD260/280 ratio was observed at any time point, whereas abnormal $28 \mathrm{~S} / 18 \mathrm{~S}$ ratios were observed at $20 \mathrm{~min}$ or later, and significant reduction of $\beta$-actin was observed at $10 \mathrm{~min}$ or later (Fig. 3, upper panels). On the other hand, samples treated with RNAlater $^{\circledR}$ at $4^{\circ} \mathrm{C}$ overnight and stored at $-80^{\circ} \mathrm{C}$ did not show any signs of RNA degradation throughout the period of the $2 \mathrm{hr}$ experiments (Fig. 3, lower panels).

\section{Preservation of RNA in RLT reagent}

In our project, an RNeasy mini kit (Qiagen) is used for RNA extraction. The stability of RNA in tissue dissolved by Buffer RLT (contained in the kit) was examined under various conditions (Fig. 4). At oneday storage, no significant changes of total RNA and OD260/280 ratio were observed for any conditions, whereas abnormal 28S/18S ratio and significant reduction of $\beta$-actin mRNA was observed in samples stored at room temperature (Fig. 4-I, E). For the 7-day stor-

Table 3. Evaluation of methods with and without RNAlater ${ }^{\circledR}$ for preservation of the quality of RNA (28S/18S ratio on RNA electrophoresis) in the tissue.

\begin{tabular}{|c|c|c|c|c|c|c|}
\hline \multirow{2}{*}{$\frac{28 \mathrm{~S} / 18 \mathrm{~S} \text { ratio }}{\text { Storage method }}$} & \multicolumn{6}{|c|}{ Storage period } \\
\hline & 1-day & 7-days & 1-month & 3-months & 6-months & 12-months \\
\hline (a) RNAlater ${ }^{\circledR},-80^{\circ} \mathrm{C}$ & ----- & ----- & ----- & ----- & ----- & $\begin{array}{l}---- \\
--1\end{array}$ \\
\hline (b) RNAlater ${ }^{\circledR}$ (removed), $-80^{\circ} \mathrm{C}$ & ---- & ----- & ----- & ----- & ----- & ----- \\
\hline (c) RNAlater ${ }^{\circledR},-20^{\circ} \mathrm{C}$ & ----- & ----- & ----- & ---- & ---- & ---- \\
\hline (d) Raw tissue in liq. $\mathrm{N}_{2}$ & ----- & ----- & ----- & ----- & $*$ & ----- \\
\hline (e) Raw tissue, $-80^{\circ} \mathrm{C}$ & ----- & * & ----- & $*$ & $*$ & ----- \\
\hline (f) Raw tissue, $-20^{\circ} \mathrm{C}$ & ----- & $* *$ & N.P. & N.P. & N.P. & N.P. \\
\hline
\end{tabular}

----: no change, *: 28S/18S<1 in a few samples, **: 28S/18S $<1$ in all samples, N.P.: not performed. Storage methods (a) - (f) are described in Table 1.

Table 4. Evaluation of methods with and without RNAlater ${ }^{\circledR}$ for preservation of $\beta$-actin mRNA quantified by Realtime PCR.

\begin{tabular}{|c|c|c|c|c|c|c|}
\hline \multirow{2}{*}{$\frac{\text { Amount of } \beta \text {-actin mRNA }}{\text { Storage method }}$} & \multicolumn{6}{|c|}{ Storage period } \\
\hline & 1-day & 7-day & 1-month & 3-month & 6-month & 12-month \\
\hline (a) $\mathrm{RNAlater}^{\circledR},-80^{\circ} \mathrm{C}$ & N.E. & N.E. & N.E. & N.E. & N.E. & N.E. \\
\hline (b) RNAlater ${ }^{\circledR}$ (removed), $-80^{\circ} \mathrm{C}$ & -----. & ----- & ----- & ----- & ----- & ----- \\
\hline (c) RNAlater ${ }^{\circledR},-20^{\circ} \mathrm{C}$ & ----- & ----- & ----- & ----- & ----- & ----- \\
\hline (d) Raw tissue in liq. $\mathrm{N}_{2}$ & ----- & ----- & ----- & ----- & $\downarrow$ & $\downarrow$ \\
\hline (e) Raw tissue, $-80^{\circ} \mathrm{C}$ & ----- & $\downarrow$ & $\downarrow$ & $\downarrow$ & $\downarrow$ & ----- \\
\hline (f) Raw tissue, $-20^{\circ} \mathrm{C}$ & ----- & $\downarrow$ & N.P. & N.P. & N.P. & N.P. \\
\hline
\end{tabular}

N.E.: not evaluated, -----: no change, $\downarrow$ : decreased (p<0.05) vs. method (a), N.P.: not performed. Storage methods (a) - (f) are described in Table 1. On the assumption that the method (a) was the best, comparisons were made against (a) at each time point. 
age, an abnormal 28S/18S ratio was observed both in samples stored at room temperature and at $4^{\circ} \mathrm{C}$ (Fig. 4II, D,E). Samples stored at room temperature also showed significant reduction in $\beta$-actin mRNA (Fig. 4II, E). Obvious signs of RNA degradation were observed at 7 days in samples stored at room temperature and $4^{\circ} \mathrm{C}$, so further examinations were not performed under these conditions.

In samples stored at -20 and $-80^{\circ} \mathrm{C}$ for one month, a significant increase in RNA yield was observed, whereas no abnormalities were noted in the OD260/280 or 20S/18S ratios (Fig. 4-III, B, C). In samples stored for 3 months, no significant changes or abnormalities were detected for any conditions (Fig. 4IV). In samples stored for 6 months, no changes were observed in any conditions except that the samples stored at $-20^{\circ} \mathrm{C}$ showed a significant decrease in $\beta$ actin mRNA (Fig. 4-V, C). For samples stored for 12 months, the samples stored at $-20^{\circ} \mathrm{C}$ showed an abnor- mal 28S/18S ratio and significant decrease in $\beta$-actin mRNA (Fig.4-VI, C).

\section{DISCUSSION}

The aim of our project is to create a database of transcriptome that is appropriate for prediction of drug toxicity in the early stage of drug development. It is therefore quite important to obtain gene expression data with high accuracy, and subsequently the method of preservation of the samples and the RNA extraction procedure are highly important. In the present study, the quality of RNA was checked in terms of the following 4 measures: amount of $\beta$-actin mRNA, 28S/18S ratio of RNA on agarose electrophoresis, yield of total RNA, and OD260/280 ratio. The amount of $\beta$-actin mRNA showed a good correlation with the $28 \mathrm{~S} / 18 \mathrm{~S}$ ratio and appeared to be more sensitive than the latter: namely, $\beta$-actin was decreased earlier than when the

I. 1 day
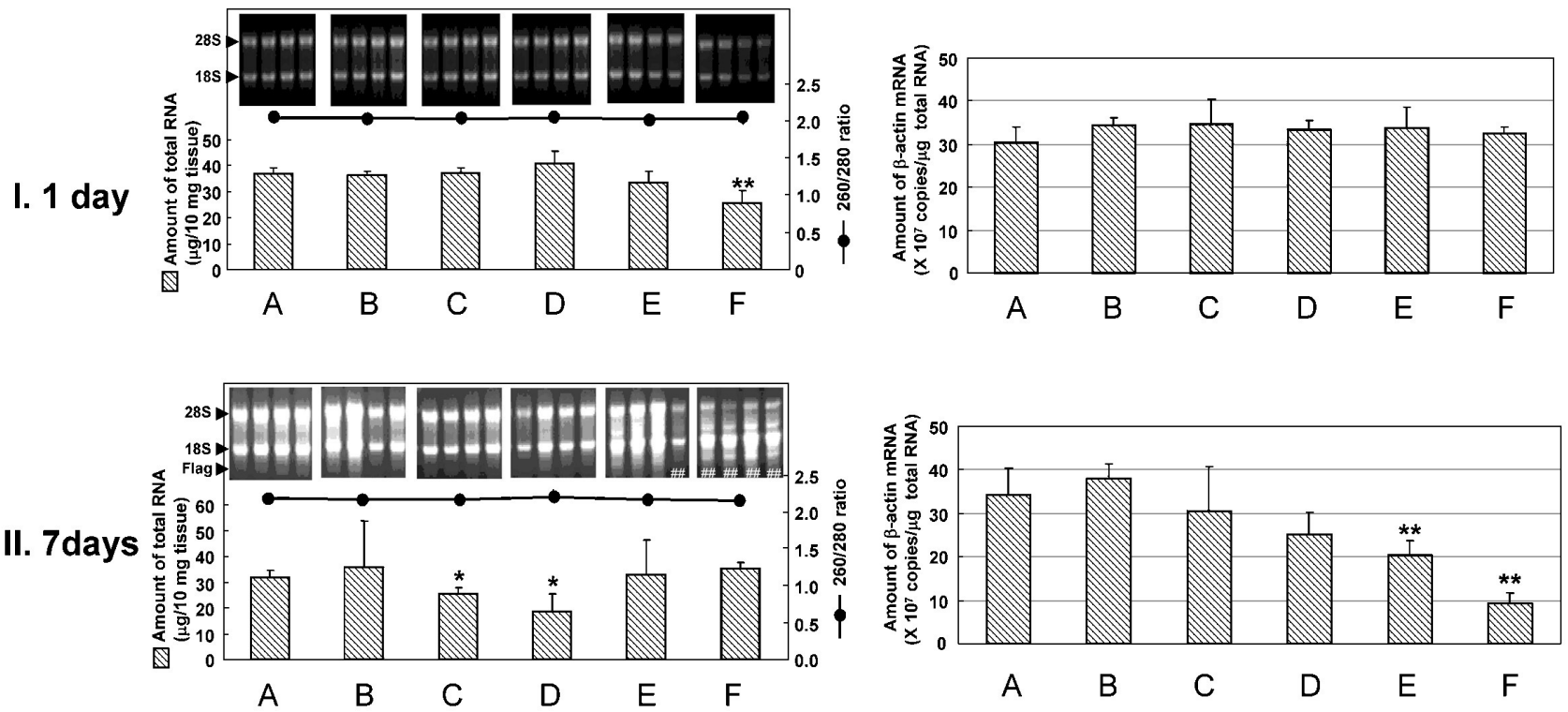

III. 1 month
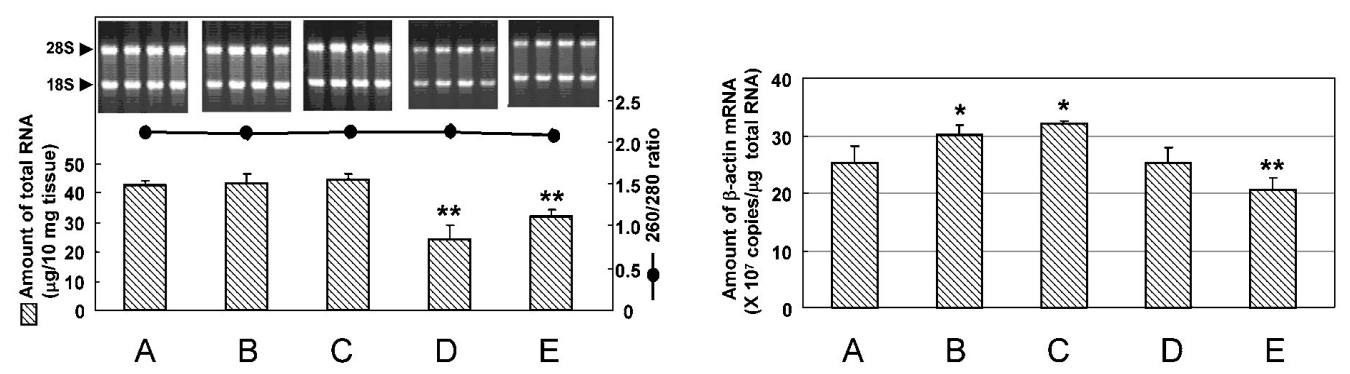

Fig. 2-1. 
Methods for preservation of mRNA quality.

IV. 3 months
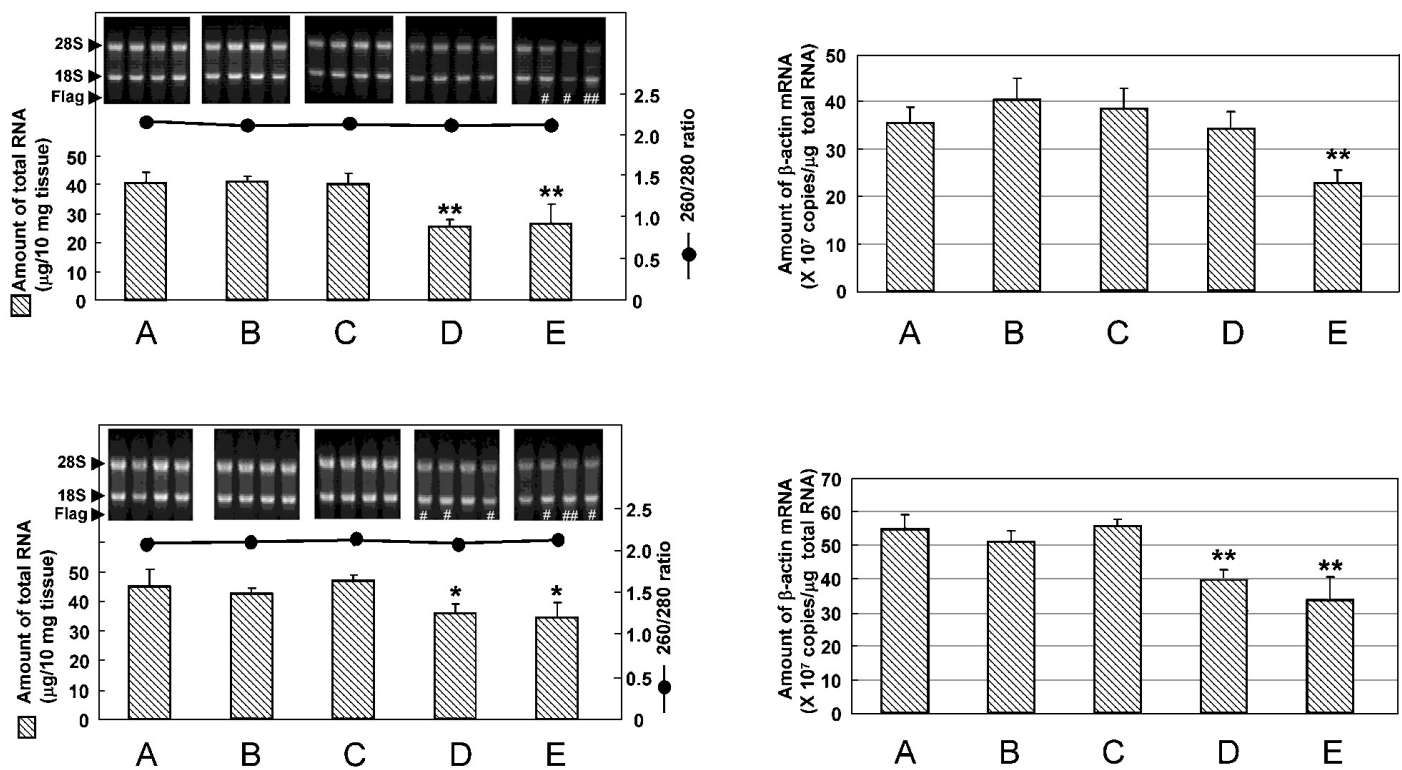

V. 6 months
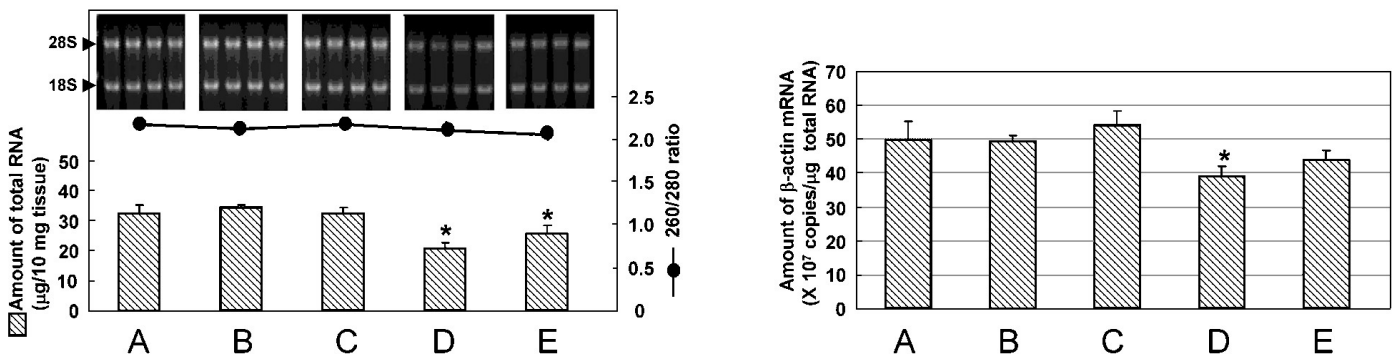

Fig. 2-2. Comparison of the methods with and without RNAlater ${ }^{\circledR}$ for preservation of tissue in terms of quality of RNA. Rat liver tissue was soaked in RNAlater ${ }^{\circledast}$ overnight at $4^{\circ} \mathrm{C}$, and stored under the following conditions: A: at $-80^{\circ} \mathrm{C}$ with RNAlater ${ }^{\circledR}$, B: at $-80^{\circ} \mathrm{C}$ after removing RNAlater ${ }^{\circledR}$, C: at $-20^{\circ} \mathrm{C}$ with RNAlater ${ }^{\circledR}$. Raw tissues without treatment with RNAlater ${ }^{\circledR}$ were stored under the following conditions: D: in liquid nitrogen, E: at $-80^{\circ} \mathrm{C}$, F: at $-20^{\circ} \mathrm{C}$. Total RNA was extracted at 1 day, 7 days, one month, 3 months, 6 months and 12 months after storage. Left panels: Total RNA was extracted from each tissue, and the amount of total RNA (bar graph) and the 260/280 ratio (line graph) were calculated and expressed as the mean \pm SD $(n=4)$. Total RNA was subjected to agarose gel-electrophoresis (upper photos), band density of $28 \mathrm{~S}$ and $18 \mathrm{~S}$ was measured by densitometer, and the ratio of the $28 \mathrm{~S} / 18 \mathrm{~S}$ band density was calculated. The Flags indicate the degradation of RNA with the following; \#; $0.8 \sim 1$, \#\#; 0.8. Right panels: Real-time PCR of $\beta$-actin was performed using cDNA synthesized from the total RNA. The amount of expression of $\beta$-actin mRNA was expressed as copy number per $1 \mu \mathrm{g}$ of total RNA. *, **Significantly different from the sample at 1 day by Student's $t$-test: ${ }^{*} \mathrm{p}<0.05$;**p $<0.01$. Raw tissue stored at $-20^{\circ} \mathrm{C}(\mathrm{F})$ was not examined later than 7 days, because it showed obvious signs of RNA degradation at the 7 th day.

abnormal ratio of $28 \mathrm{~S} / 18 \mathrm{~S}$ ratio was detected. The total yield of RNA and OD260/280 ratio were not correlated with the $28 \mathrm{~S} / 18 \mathrm{~S}$ ratio. This could be due to employment of the column method for extraction of RNA where degraded short RNA chains were also harvested. The OD 260/280 ratio is an index of the contamination of proteins and thus showed no abnormalities in the case of RNA degradation.

Whether the normal range of these parameters assures the quality of RNA for GeneChip analysis is another question. It is well known that the stability of RNA varies largely between genes (Timofeeva et al., 2000), and degradation of RNA differentially affects each probe set for a gene (Thach et al., 2003). Therefore, the present study does not necessarily assure quantification of each gene expression. However, it is not practical to perform GeneChip analyses for all the conditions in the present study in order to assess the 
individual stability of all the genes. Here we offer the minimal requirement for construction of the database for Toxicogenomics.

According to the manufacturer's protocol, the samples are to be preserved by RNAlater ${ }^{\circledR}$ for 1 week under room temperature and for 4 weeks under $4{ }^{\circ} \mathrm{C}$. Similar results were obtained in our laboratory. As for the amount of $\beta$-actin mRNA in the sample stored with RNAlater $^{\circledR}$ at room temperature, some reduction was observed at 3 days and obvious reduction was detected at 8 days, whereas no reduction of RNA quality was detected under $4^{\circ} \mathrm{C}$ as long as 15 days. Therefore, we concluded that the sample soaked in RNAlater ${ }^{\circledR}$ could be stored at room temperature for a few days, but preferentially should be stored in a refrigerator which would make it possible to keep it for at least 2 weeks.

The manufacturer's protocol recommends removing RNAlater ${ }^{\circledR}$ after overnight treatment when preserved in the freezer. In our project, however, we harvested 160 samples ( $N=5$ for each of 4 time and 4 dose points in a duplicated manner) per experiment, but 48 of them ( $\mathrm{N}=3$ for each of 4 time and 4 dose points) were analyzed by GeneChip. This means only $30 \%$ of the tubes are homogenized and the remaining ones are stored for backup, so it is quite cumbersome if RNAlater $^{\circledR}$ is to be removed from all the tubes. We compared RNA quality between samples frozen with and without RNAlater ${ }^{\circledR}$ and no difference was observed. It appears that RNAlater ${ }^{\circledR}$ can be left during storage in the frozen state, at least in the case of liver tissue.

For samples stored in liquid $\mathrm{N}_{2}$ or at $-80^{\circ} \mathrm{C}$, some signs suggesting RNA degradation appeared until 6 months, whereas degradation tended to reduce by 12 months. This irrational result might be explained as follows. In the experiments shown in Fig. 2, the samples should have been thawed before homogenization, and this took 5 to $10 \mathrm{~min}$ because there were so many tubes. The total number of the samples was small when the 12-month samples were processed, and thus the time for processing was shorter than the other time points. This suggested that the time from thawing to
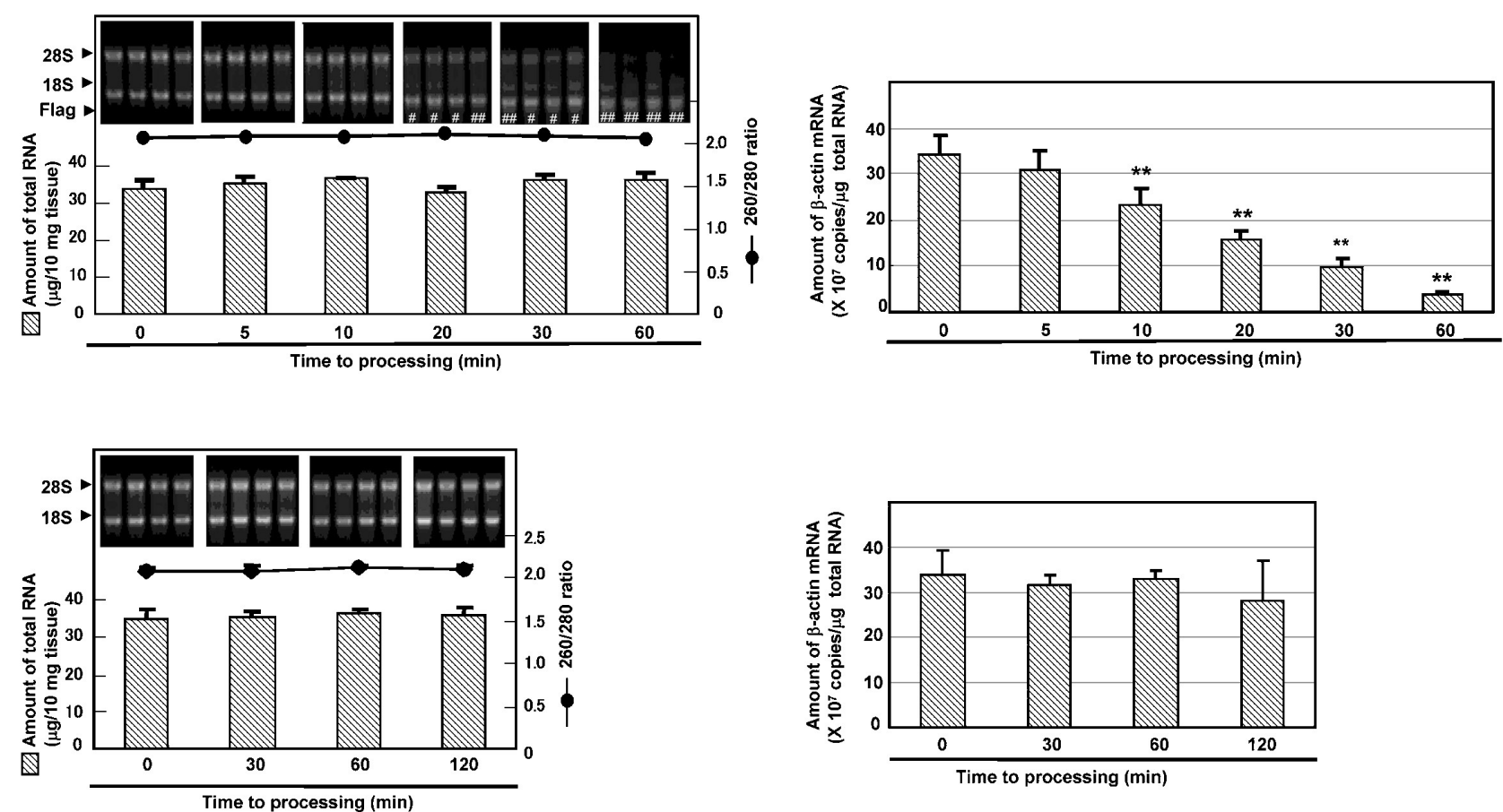

Fig. 3. Effects of freezing-thawing on the RNA quality in the sample.

Upper panels: Non-treated samples were taken out from liquid nitrogen and left for 0, 5, 10, 20, 30 or 60 min under room temperature and then lysed in buffer RLT.

Lower panels: RNAlater ${ }^{\circledR}$-fixed samples were taken out from the deep freezer and left for 0,30 , 60, or 120 min under room temperature and then lysed in buffer RLT. Checking of RNA quality (left panels) and quantification of $\beta$-actin mRNA by realtime PCR (right panels) were performed in the same way as in Fig 2. 
Methods for preservation of mRNA quality.

homogenization affected RNA quality. In order to confirm this, we compared these samples: frozen without preservative in liquid $\mathrm{N}_{2}$ and frozen at $-80^{\circ} \mathrm{C}$ after RNAlater $^{\circledR}$-treatment by leaving them to thaw. In the

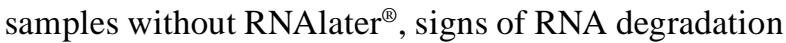
appeared at 10 min or later, whereas RNA appeared to be stable in the RNAlater ${ }^{\circledR}$-treated samples for at least 2 hrs. It also appeared that degradation of RNA was more dependent on the time of thawing than that of storage when stored without preservatives. This clearly means that storage in RNAlater ${ }^{\circledR}$ has a merit in processing many frozen samples at once without concern for RNA degradation. The manufacturer's note points out that RNAlater ${ }^{\circledR}$-treated samples can be repeated in the freezing-thawing cycle up to 10 times. We also confirmed this description (data not shown), although freezing-thawing is restricted to once in our general protocol.

The manufacturer's note also describes that RNAlater ${ }^{\circledR}$ is useful in preserving cultured cells, i.e., cells are scraped from the plates, harvested by centrifugation and RNAlater ${ }^{\circledR}$ added to the pellet. However, this procedure is quite cumbersome and might affect gene expression in the cell. In our project, we directly dissolved the cells by Buffer RLT Reagent, a component of the RNA-extraction kit. It would be quite convenient if the RNA in the dissolved sample were stable under this condition. The present experiments using liver tissues demonstrated that the RNA in samples dissolved in the buffer appeared to be stable for at least one year at $-80^{\circ} \mathrm{C}$ or in liquid $\mathrm{N}_{2}$.

From the experiments described above, we offer
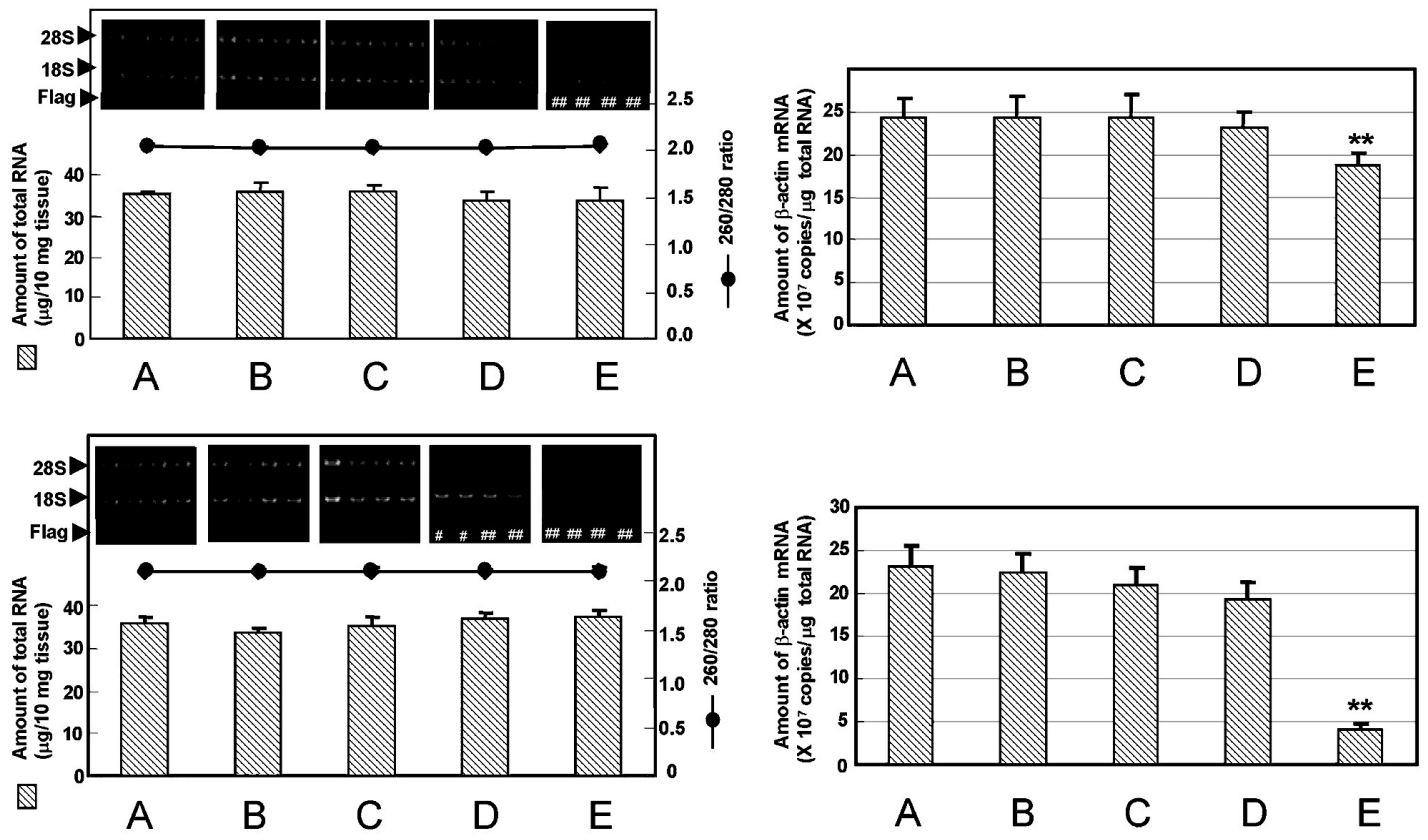

III. 1 month
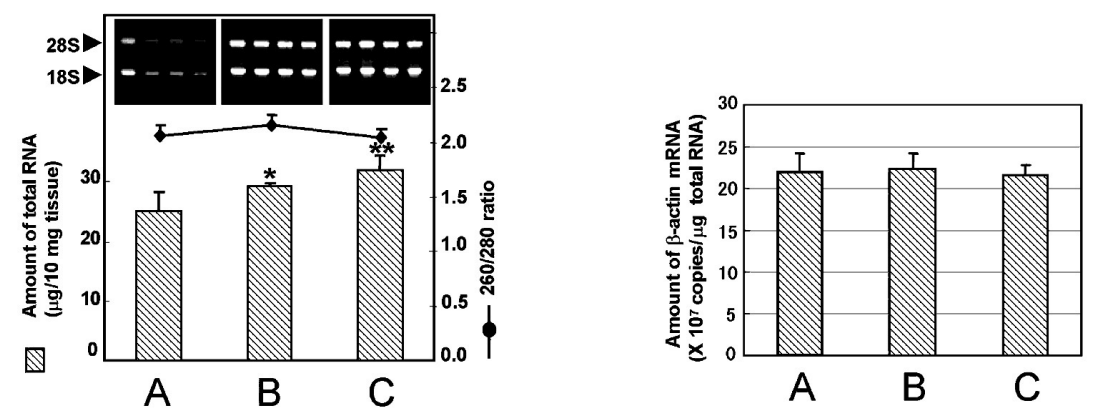

Fig. 4-1. 
IV. 3 months

\section{6 months}
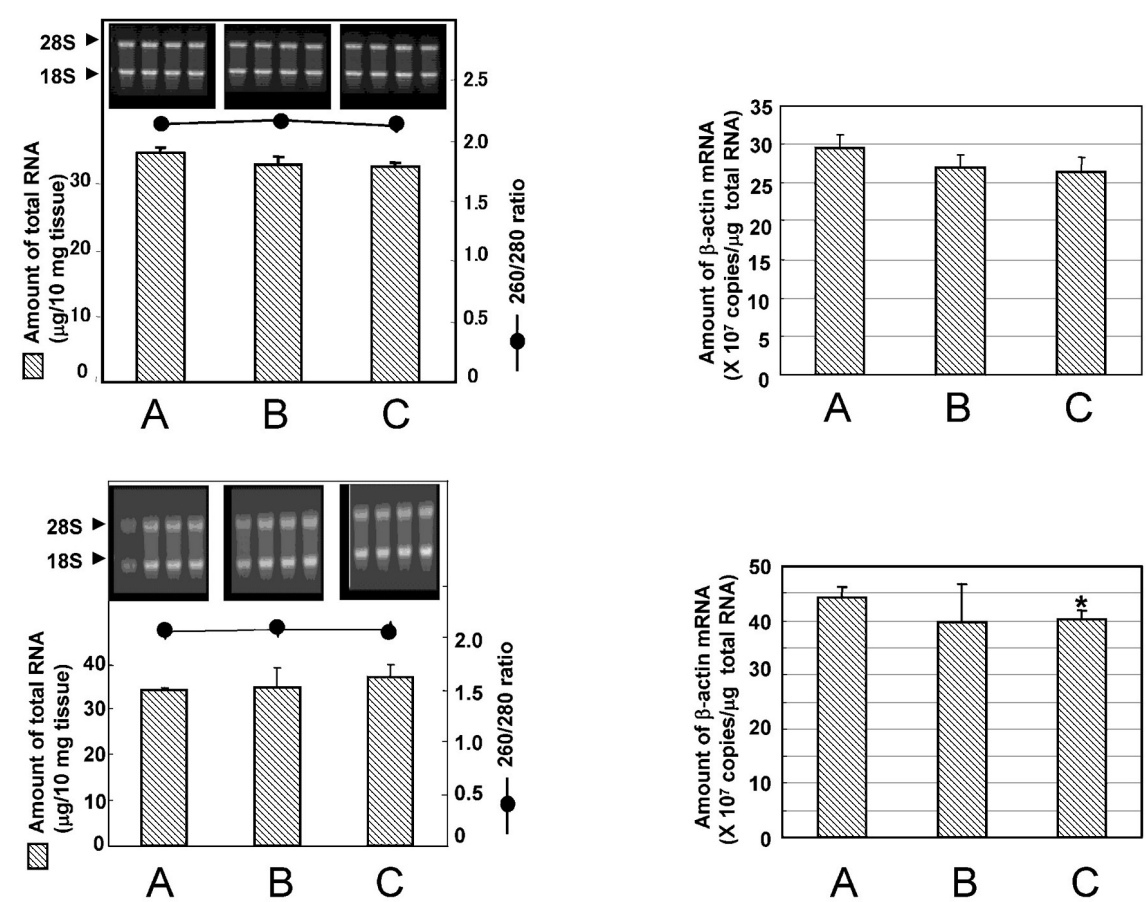

\section{12 months}
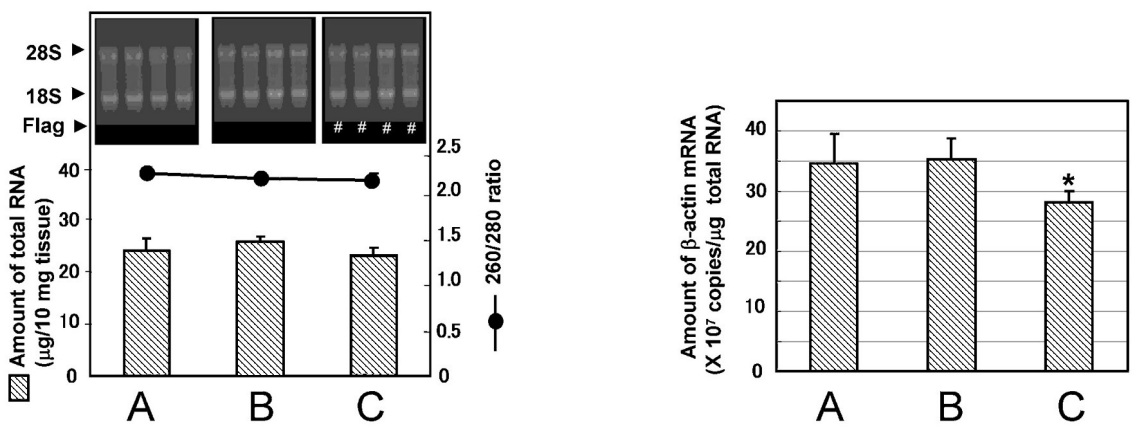

Fig. 4-2. Evaluation on stability of RNA in the sample dissolved in Buffer RLT. Rat liver tissue was dissolved in buffer RLT. The liver lysate, $100 \mu \mathrm{l}$ each, was dispensed to microtubes and stored under the following conditions: A: in liquid nitrogen, $\mathrm{B}:-80^{\circ} \mathrm{C}$, C: $-20^{\circ} \mathrm{C}$, D: $4^{\circ} \mathrm{C}$, E: room temperature. Total RNA was extracted 1 day, 7 days, one month, 3 months, 6 months and 12 months after storage. Checking of RNA quality (left panels) and quantification of $\beta$-actin mRNA by real-time PCR (right panels) were performed in the same way as in Fig 2. The lysates stored at $-20^{\circ} \mathrm{C}$ and room temperature (D, E) were not examined later than 7 days, because they showed obvious signs of RNA degradation at the 7th day.

the following protocol as a minimum requirement for RNA extraction from rat liver for GeneChip analysis.

1. Liver tissues are to be dissected into $5 \mathrm{~mm}$ cubic pieces on ice and put into a tube containing more than 10 volumes of chilled RNAlater ${ }^{\circledR}$ as soon as possible. A disposable biopsy punch is useful for this purpose.

2. The tissue samples are to be fixed in RNAlater ${ }^{\circledR}$ overnight at $4^{\circ} \mathrm{C}$. It can be stored at least one day at room temperature, and 2 weeks at at $4^{\circ} \mathrm{C}$, in the non-frozen state.

3. For longer storage of RNAlater ${ }^{\circledR}$-fixed samples, they should be kept under $-20^{\circ} \mathrm{C}$ and are stable for at least one year. For this purpose, RNAlater ${ }^{\circledR}$ is not necessarily removed.

4. When RNA is extracted from samples treated with RNAlater ${ }^{\circledR}$ and frozen for storage, they should be homogenized with Buffer RLT within 2 hr.

5. The samples dissolved in Buffer RLT can be stored for at least one year without RNA degrada- 
Methods for preservation of mRNA quality.

tion at $-80^{\circ} \mathrm{C}$.

\section{ACKNOWLEDGMENT}

This study was supported in part by a grant from the Ministry of Health, Labor and Welfare (H14-Toxico-001).

\section{REFERENCES}

Grotzer, M.A., Patti, R., Geoerger, B., Eggert, A., Chou, T.T. and Phillips, P.C. (2000): Biological stability of RNA isolated from RNAlater-treated brain tumor and neuroblastoma xenografts. Med. Pediatr. Oncol., 34, 438-442.

Kasahara, T., Kakinuma, C., Kuwayama, C., Hashiba, M., Harada, T. and Degawa, M. (2005): Increase in expression of $\mathrm{p} 21$ during a process of tamoxifen-induced hepatocarcinogenesis in female rats. J. Health Sci., 51, 185-190.

Mutter, G.L., Zahrieh, D., Liu, C., Neuberg, D., Finkelstein, D., Baker, H.E. and Warrington, J.A. (2004): Comparison of frozen and RNALater solid tissue storage methods for use in RNA expression microarrays. BMC Genomics, $\mathbf{5}, 88$.

Rodrigo, M.C., Martin, D.S., Redetzke, R.A. and Eyster, K.M. (2002): A method for the extraction of high-quality RNA and protein from sin- gle small samples of arteries and veins preserved in RNAlater. J. Pharmacol. Toxicol. Methods, 47, 87-92.

Snedecor, G.W. and Cochran, W.G. (1989): Statistical Methods, $8^{\text {th }}$ ed., Iowa State University Press.

Thach, D.C., Lin, B., Walter, E., Kruzelock, R., Rowley, R.K., Tibbetts, C. and Stenger, D.A. (2003): Assessment of two methods for handling blood in collection tubes with RNA stabilizing agent for surveillance of gene expression profiles with high density microarrays. J. Immunol. Methods, 283, 269-279.

Timofeeva, A.V., Skrypina, N.A., Savochkina, L.P. and Beabealashvilli, R. Sh. (2000): Size distribution of the urokinase mRNA decay intermediates in different tissues and cell lines. Biochim Biophys Acta. 1517, 33-45.

Urushidani, T. and Nagao, T. (2005): Toxicogenomics: The Japanese initiative. In Handbook of Toxicogenomics - Strategies and Applications (Borlak, J., ed.), pp. 623-631. Wiley - VCH.

Wang, W.H., McNatt, L.G., Shepard, A.R., Jacobson, N., Nishimura, D.Y., Stone, E.M., Sheffield, V.C. and Clark, A.F. (2001): Optimal procedure for extracting RNA from human ocular tissues and expression profiling of the congenital glaucoma gene FOXC1 using quantitative RT-PCR. Mol. Vis., 7, 89-94. 